\title{
ENHANCING ENZYMATICALY TREATED HAY SUBSTRATE BIOMETHANE POTENTIAL USING BIODEGRADABLE SURFACTANTS
}

\author{
Eriks Skripsts ${ }^{1,2}$, Linda Mezule ${ }^{1,2}$, Elvis Klaucans ${ }^{1,2}$, Estere Romanovska ${ }^{1,2}$ \\ ${ }^{1}$ Bio RE, Ltd., Latvia; ${ }^{2}$ Riga Technical University, Latvia \\ eriks.skripsts@biore.lv, linda.mezule@rtu.lv, elvis.klaucans@biore.lv, estere@biore.lv
}

\begin{abstract}
Second-generation biofuel production from grassland biomass is getting more and more popular as a research topic. A zero-to-low waste production strategy is one of the core ideas in the technology design. Biogas production from lignocellulose is one of the promising components in technology development, which can solve the upcoming remaining lignocellulose problems. This study is looking into lignocellulose leftovers after sugar extraction as a substrate for anaerobic digestion enhancing the fermentation process with surfactant usage. Biomethane potential tests were used to test the remaining biomass. It has relatively high biomethane potential up to $378.31 \mathrm{mlCH} 4 \cdot \mathrm{gVS}^{-1}$, but enzymatic hydrolyses leftovers show the substrate toxicity characteristics at a concentration higher than $2.5 \%$ from total volatile solids loaded. The biomethane formation inhibition process can be related to an increase in phenol concentration, ethic was measured using the colorimetric analyses method, although it is not the only factor that is leaving an influence on the fermentation process. The study shows biodegradable surface-active substance positive influence on the used substrate biomethane potential increasing it on average by $50 \%$. There was no evidence found on the different positive effects for surfactants with different chemical structures.
\end{abstract}

Keywords: enzyme treated biomass substrate, biogas, biodegradable surfactants, digestion, biomethane potential, lignocellulose digestion.

\section{Introduction}

Renewable fuel consumption is increasing by each year and in 2016 it accounted for around $4 \%$ of the world's road transport. Part of the renewable fuels is produced from food crop-originated biomass. The European Union had set a target to decrease the biofuel production from food crops from $7 \%$ to $3.8 \%$, and it is regulated by the Renewable Energy Directive 2020-2030 [1]. Biomass-derived from grasslands is an alternative biomass source. Lignocellulosic deposits represent a great source of sugars, with a huge availability on the Earth [2] and estimated productivity of around 2.3 billion L of biofuel by 2020 [1]. Many research groups are developing zero-to-low waste enzymatic hydrolyses technologies for grass biomass conversion into renewable fuels. Although, after the enzymatic hydrolyses a large fraction of non-hydrolyzed grass or hay substrate is leftover [3]. Anaerobic Fermentation (AF) of Hydrolyzed Hay Substrate over-lefts (HHS) can be a powerful tool to create a complete zero-to-low waste renewable fuel production technology from grassland biomass.

The chemical content of dried hay can vary according to the harvest conditions, season, and grass species, but on average hay contains around $9.4-18.9 \%$ of protein and 58-72\% lignocellulose components according to Zervas G. et al. findings [4]. At the same time, Kumar D. et al. and Lynd L.R. et al. data show that lignocellulose biomass is a complex matrix of mainly three components: cellulose $(20-50 \%)$, hemicellulose $(15-35 \%)$, and lignin $(5-30 \%)$ [5; 6]. Remaining biomass after the enzyme hydrolyses is still rich in energy although the main part of cellulose and hemicellulose have been removed by the hydrolyses process and membrane separation. Almost all non-degraded protein, hemicellulose, and lignin are still left in the biomass [7]. These nutrients are key factors of interest for the AF process due to the reason that the hydrolyses process has already taken place, therefore there is evidence to think that the $\mathrm{AF}$ fermentation process will take place faster comparing to normal grass hay feedstock.

The cellulose, hemicellulose, and protein AF degradation are well studied and known, but there are still open questions about the AF degradation of lignin compounds. Grass lignin consists of guaiacyl, syringyl, and p-hydroxyphenyl (p-coumaryl) three-dimensional heterogeneous polymer units, where more than $90 \%$ of the guaiacyl monomers are connected by ether and carbon-carbon linkages. pCoumaric acid makes up $5-10 \%$ of the lignin and is mostly esterified at the $\Upsilon$-position of its propyl group [8].

Lignin is one of the most popular AF feedstocks, because it is in the lignocellulose content. But the AF process is still not so commonly studied. Several anaerobic bacterial species are defined which can 
degrade lignin compounds under anaerobic conditions. Mechici T. et al. have found that several Clostridium sp [9] and Wu Y.R et. al. detected that Methanoculleus sp. [10] can degrade the lignin type compounds, as well as other authors have found that the same performance is showing species like Acetoanaerobium sp [11], Rhodococcus justice [12], and Sporomusa sp. [13]. There is a relatively superficial understanding of phenol anaerobic degradation mechanisms. Khan M. U. and Ahrig K.B. in their review about lignin degradation under anaerobic conditions show that pre-treated lignin (oxidative pre-treatment) conversion into methane is taking place, true lignin de-Methoxalation into lignin fragments, which leads to aromatic ring cleavage into aliphatic acids (adipic acid, heptanoic acid pimelic acid), which are then used as hydrogenotrophic methanogenesis substrate [14].

One of lignin degradation side products is phenols and phenolic compounds [15], which at high concentration can leave a negative impact on the AF process. In concentration lover than $0.50 \mathrm{~g} \cdot \mathrm{L}^{-1}$ phenol compounds are getting degraded within 8 days but at $1-1.50 \mathrm{~g} \cdot \mathrm{L}^{-1}$ phenol degradation is noted only after 16 and 40 days, respectively. Phenol degradation was not detected when the concentration reaches 2 and $4 \mathrm{~g} \cdot \mathrm{L}^{-1}$ [16]. The beginning of the second phase of biogas production was inversely linked to phenol concentration, suggesting that phenol degradation may be inhibited by phenol, as already noted by Wang et al. [17] at concentrations exceeding $0.60 \mathrm{~g} \cdot \mathrm{L}^{-1}$, or by Rosenkranz et al. [18] at concentrations exceeding $0.80 \mathrm{~g} \cdot \mathrm{L}^{-1}$. This hypothesis is also supported by the fact that phenol at higher levels $\left(2.00 \mathrm{~g} \cdot \mathrm{L}^{-1}\right)$ was not significantly degraded to biogas, even after 140 days [19].

Some latest researchers of AF are looking into different biodegradable surfactant usage to stabilize the process itself. Surfactant usage in Waste Activates Sludge AF is getting more attention from the research groups. Anaerobic fermentation is a complex process - hydrolysis, acidification, and methanogenesis are taking place almost simultaneously. Surfactants, owing to special characteristics, have some positive and negative effects on sludge during AF stages. The hydrolysis efficiency increase by surfactant can be summed up in two aspects: sludge components and enzyme activity the sludge blocks are dispersed, and the hydrolases and other enzymes will be released from the sludge, which increases the efficiency of hydrolysis [20]. Studies done by Xu L et. al show that surfactants are leaving a positive influence on the acidification process increasing the acetic acid concentration comparing to another short-chain fatty acid, (SCFA) like propionic, iso-valeric, and propionic acid, which has a bigger negative impact on the following methanogenesis process comparing to acetic acid [21]. At the moment, there is no proof that recalcitrant SAS are leaving a positive impact on the methanogenesis phase, however ,sodium dodecyl sulfate is leaving a minor negative effect comparing to sodium dodecyl benzene sulfonate [22]. There is a lack of research in biologically degradable SAS use and its effect on the AF process, therefore, this study will deal with these questions.

\section{Materials and Methods}

\section{Hay substrate after enzymatic cellulose hydrolyses (HHS)}

Dried hay (dry weight (DW): $92.8 \pm 1.3 \% ; 6.02 \%$ ash) from semi-natural grasslands was collected and stored at room temperature, then milled by a mechanical cutting mill (Retsch SM100, Haan, Germany) to obtain particle size $<0.5 \mathrm{~cm}$. The ground hay was mixed $(3 \% \mathrm{w} / \mathrm{v})$ with nano filtered permeate water and boiled in a closed hydrolysis reactor unit $(20 \mathrm{~L})$ until the temperature reached 120 ${ }^{\circ} \mathrm{C}$, then it was cooled until $37^{\circ} \mathrm{C}$. After cooling, the stock enzyme mix (13 FPU per mL, obtained from Irpex lacteus) was added into the reactor to obtain a final enzyme concentration in the ranges of 0.1-0.2 FPU per $\mathrm{mL}$ of the reaction liquid. The enzymatic hydrolysis was carried out for $24 \mathrm{~h}$ at $37{ }^{\circ} \mathrm{C}$. After completion of the hydrolysis, the liquid hydrolysate was pumped through a rough filter system (pore size of $\sim 1 \mathrm{~mm}$ ) to remove biomass particles. The biomass that was used as a substrate in BMP tests had the following chemical parameters: total solids $(\mathrm{TS})=17.98 \%$, volatile solids $(\mathrm{VS})=17.51 \%$, $\mathrm{pH}=6.2$.

\section{Surface active substances}

In anaerobic fermentation tests biodegradable Surface-Active Substances (SAS) were used in order to enhance the hydrolyses process [22]. Since the technical SAS were used, it is not possible to show the exact chemical composition for the substance. The full information was not given by manufacturers, therefore only brand names and main component names are shown. Available chemical parameters for SAS used are shown in Table 1. 
Surface active substances data

Table 1

\begin{tabular}{|c|c|c|c|c|c|c|}
\hline $\begin{array}{c}\text { SAS brand } \\
\text { name }\end{array}$ & $\begin{array}{c}\text { SAS } \\
\text { type }\end{array}$ & $\begin{array}{c}\text { Main chemical } \\
\text { compound }\end{array}$ & LC50 value & CMC & $\begin{array}{c}\text { HLB } \\
\text { value }\end{array}$ & Data source \\
\hline Lansurf & $\begin{array}{c}\text { Non- } \\
\text { ionic }\end{array}$ & $\begin{array}{c}\text { Alkoxylated } \\
\text { Polyethylene } \\
\text { glycol Mono } \\
\text { Oleate }\end{array}$ & $\begin{array}{c}108 \mathrm{mg} \cdot \mathrm{L}^{-1} \\
\text { (Fish) }\end{array}$ & N.A & 10.4 & $\begin{array}{c}\text { Lankem Ltd. } \\
\text { issued MSDS }\end{array}$ \\
\hline Aura-Pure & Anionic & $\begin{array}{c}\text { Proteo lipid } \\
\text { with alkali } \\
\text { chanes based on } \\
\text { natural faty } \\
\text { acids }\end{array}$ & $\begin{array}{c}136 \mathrm{mg} \cdot \mathrm{L}^{-1} \\
\text { (Daphnia } \\
\text { Magna, } 48 \mathrm{~h})\end{array}$ & $\begin{array}{c}350 \\
\mathrm{mg} \cdot \mathrm{L}^{-1}\end{array}$ & 7 & $\begin{array}{c}\text { Happy Fish } \\
\text { Ltd. issued } \\
\text { MSDS }\end{array}$ \\
\hline $\begin{array}{c}\text { Bis- } \\
\text { acyloxyethyl } \\
\text { hydroxyethyl } \\
\text { methyl } \\
\text { ammonium } \\
\text { methylsulfate } \\
\text { with an alkyl } \\
\text { chain based on a } \\
\text { natural fatty } \\
\text { acid. }\end{array}$ & $\begin{array}{c}2.23 \mathrm{mg} \cdot \mathrm{L}^{-1} \\
\text { (Daphnia }\end{array}$ & Magna, $48 \mathrm{~h})$ & N.A & N.A & $\begin{array}{c}\text { Mosselman } \\
\text { s.a. issued } \\
\text { MSDS }\end{array}$ \\
\hline
\end{tabular}

For all tested SAS, manufacturing companies claimed that they are biodegradable in the aquatic environment at aerobic conditions. The pre-experiments showed that the presence of SAS is leaving a positive impact on the AF process. The optimal concentration was determined in pre-experiment and following the producers' recommendations. The surfactant concentration was taken at $350 \mathrm{mg} \cdot \mathrm{L}^{-1}$, which is a critical micelle concentration for the chosen anionic surfactant (manufacturer's data).

\section{BMP test description}

Since there still is no standardized Biomethane Potential (BMP) determination procedure including the standardized measurement equipment, substrate loading ration, inoculum standardization, etc. [23], the automated BMP test was performed in a laboratory designed BMP test Bach type equipment. It consisted of an incubator unit able to sustain $25-60^{\circ} \mathrm{C}$, orbital shaker (Ohaus- HEAVY DUTY ORBITAL SHAKERS) with rotation orbital $2 \mathrm{~cm}$ and max rotation speed of $500 \mathrm{RPM}$. Biogas is being measured with Anaero Technology 15 Channel automatic Gas Flowmeter in combinations with RITTER MilliGascounters single channel gas flow meter. Before the measurement, biogas was cleaned through $3 \mathrm{M} \mathrm{NaOH}$ to neutralize present $\mathrm{CO}_{2}$ and measure just the outcoming methane yield [24].

\section{Inoculum preparation}

Inoculum was taken from the Municipal Waste Water Treatment Plant (WWTP) anaerobic digester, where primary and secondary sludge fermentation takes place, and held in room temperature for 7 days. After holding it still, the inoculum was frozen down to- $80{ }^{\circ} \mathrm{C}$ (Global Cooling Inc. Model Stirling Ultracold ULT-25NE) in order to use it for different experiment setups. After thawing the chemical parameters for the inoculum were the following: total solids $(\mathrm{TS})=3.1 \%$, volatile solids $(\mathrm{VS})=2.9 \%$, $\mathrm{pH}=7.9, \mathrm{FOS} / \mathrm{TAC}=0.31$.

\section{Sample preparation and $A F$ conditions}

The fermentation was done in $1000 \mathrm{~mL}$ batch type reactors with a loading coefficient of 0.5 in order to sustain a proper mixing at $250 \mathrm{rpm}$ with sequence $15 \mathrm{~min}$ mixing and $15 \mathrm{~min}$ standstill. For all the AF samples the same inoculum was used after thawing it and leaving it at room temperature overnight. After mixing all the necessary components each reactor was mixed and flushed with $\mathrm{N}_{2}$ gas $(99.99 \%$, AGA gas) for $60 \mathrm{sec}$ and placed in shacking incubator at $37^{\circ} \mathrm{C}$ for 30 days fermentation. The gas was collected and cleaned through $3 \mathrm{M} \mathrm{NaOH}$ and the remaining $\mathrm{CH}_{4}$ amount was measured using on-line measurement units. All samples and inoculum were tested in triplicates, and the results were given as 
mean values showing the standard deviation. In each fermentation cycle, the inoculum alone was controlled - prepared using inoculum alone to correct for the endogenous biogas production. Samples containing just the inoculum were repeated at each separate fermentation.

\section{Phenolic index procedure}

In order to determine the phenol concentration changes during the HS fermentation the modified standard Phenolic index 5 test from Macherey Nagel was used. A method is capable to measure Phenolic compounds from 0.2 to $5.0 \mathrm{mg} \cdot \mathrm{L}^{-1}$. The sample preparation was done by centrifuging the sample for 30 min at $4400 \mathrm{rpm}$ in Eppendorf Centrifuge Model 5702. After the centrifugation, the supernatant is clear enough to use for spectrophotometric analyses. As a reference, the non-treated sample was used in order to minimize the matrix effect. The analyses were done in triplicates showing the mean value together with standard deviation.

\section{FOS/TAC measurement procedure}

To understand the AF systems' balance and get a vision about system stability, it was found that a useful tool is to measure the Volatile Organic Acids content (FOS) and the buffer capacity (TAC) ratio. The analyses were done on the first and last day of fermentation due to the technical specifics of batch fermentation. Analyses were done using the manual titration method with $1 \mathrm{~N} \mathrm{H}_{2} \mathrm{SO}_{4}$, according to Lili M. et al. new titration method. The systems' stability was evaluated according to suggested parameters, see Table 2 [25].

Table 1

Evaluation of FOS/TAC ratios according to empirical experience

\begin{tabular}{|c|c|c|}
\hline FOS/TAC ratios & Background & Suggestion/Counter Action \\
\hline$>0.6$ & Highly excessive biomass input & Stop adding biomass \\
\hline $0.5-0.6$ & Excessive biomass input & Add less biomass \\
\hline $0.4-0.5$ & Plant is overflowing & Monitor the plant more closely \\
\hline $0.3-0.4$ & Biogas production at the maximum & Keep biomass input constant \\
\hline $0.2-0.3$ & Biomass input is too low & Slowly increase the biomass input \\
\hline$<0.2$ & Biomass input is far too low & Rapidly increase the biomass input \\
\hline
\end{tabular}

\section{Data analyses}

MS Excel 2013 t-test (two-tailed distributional (significance level $\alpha \leq 0.05$ ) was used for the analysis of variance on data from various sample setups. Data variation was represented by standard deviation from at least 3 replicates.

\section{Results and discussion}

\section{Hydrolyzed hay substate BMP}

In pre-experiments with HHS, the substrate inhibiting effect has been detected correlating the substrate concentration increase, therefore the full BMP analyses for 30 days were performed for hay concentration 2.5, 5 and 10\% from total volatile solids (VS) loaded. The experiment set up was prepared according to the above mentioned procedure and the total VS loading was kept equal to all the experiments

Variation in biomethane potential over the different substrate loading shows that HHS is having a toxic effect on $\mathrm{AF}$ at the concentration starting from 5\%, and substrate concentration increase is followed by even bigger BMP loss. Nevertheless, HHS has relatively high BMP comparing to other substrates $2.5 \%$ from VS, $5 \%$ and $10 \%$ giving $378.81 \mathrm{mlCH}_{4} \cdot \mathrm{gVS}^{-1}, 360.93 \mathrm{mlCH}_{4} \cdot \mathrm{gVS}^{-1}$ and $289.91 \mathrm{mlCH}_{4} \cdot \mathrm{gVS}^{-}$ ${ }^{1}$, respectively. Comparing to maize silage, BMP is varying from $380-388 \mathrm{mlCH}_{4} \cdot \mathrm{gVS}^{-1}$ at organic loading 5.5 and $17.1 \mathrm{kgVS} \cdot \mathrm{m}^{-3}$ mass loaded [26]. Hydrolyzed hay substrate biomass loading can be significantly lower compared to popular feed stock maize silage, therefore its usage in biogas production can be considered a co-digestion substrate together with the main agricultural or organic waste-derived substrate.

During AD digestion samples were tested for the phenolic index changes to follow the lignin degradation and phenolic compound concentration changes during AF (Fig. 2.). The author Wang in his study about the phenol degradation in the AF process notes that increase in phenol concentration is leading to AF process inhibition [27]. It is well seen that phenol concentration is increasing during AF. 
The bigger the HHS loading, the faster the phenol concentration is rising over time. There is a reverse correlation between the phenol concentration increase and BMP decrease over the HHS loading increase. Although the measured phenol concentrations are 1000-fold smaller than the concentrations noted in Wang et. al. research, it still gives enough evidence to say that increase in phenol concentration is leaving a negative effect on BMP already starting from $1 \mathrm{mg} \cdot \mathrm{L}^{-1}$ at day 16 , but on day 30 comparing to most effective HHS concentration increase in the phenol index to up $3.25 \mathrm{mg} \cdot \mathrm{L}^{-1}$, is leading to $23 \%$ decrease in the BMP outcome.

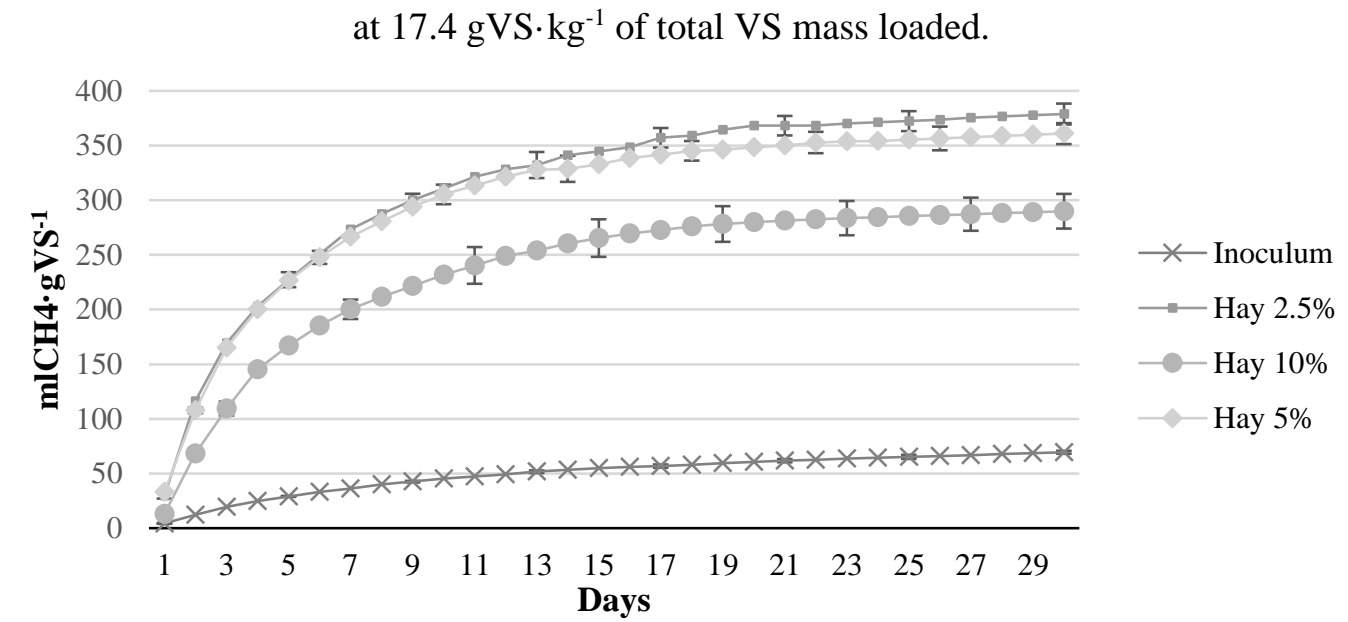

Fig. 1. Hydrolysed hay substrate BMP

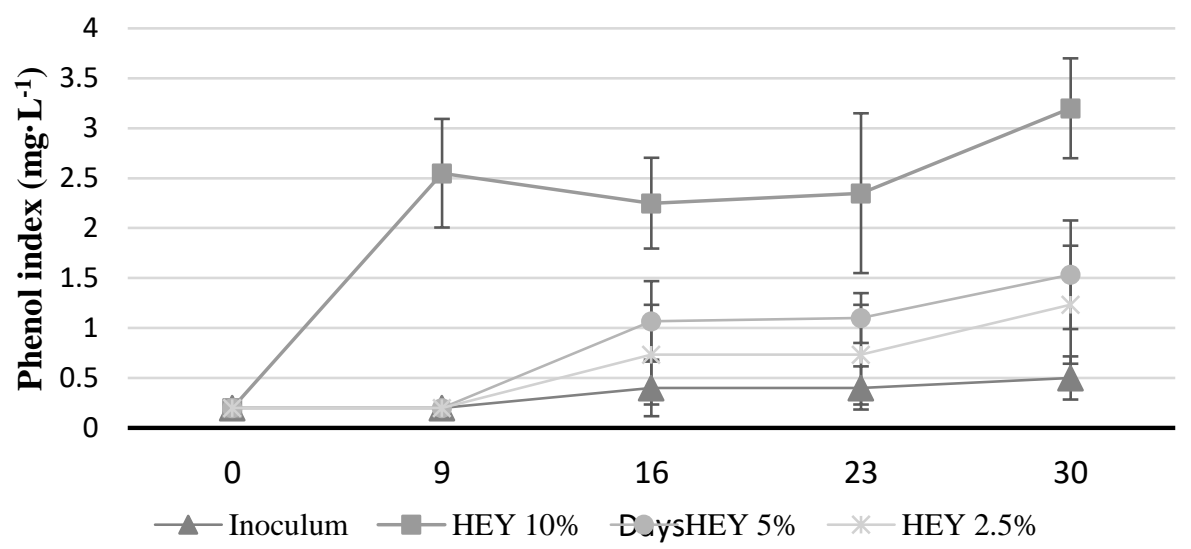

Fig.2. Phenol index changes during fermentation

There is not enough evidence to say that phenol type compounds are the only thing that causes methane production inhibition in these fermentation systems, but most likely it is one of the reasons, because the performed FOS/TAC analyses show that substrate digestion is taking place at normal rates. The FOS/TAC were measured on day 1 and day 30 for all the samples including the inoculum (Table 3 ).

FOS/TAC Changes over AF

Table 2

\begin{tabular}{|c|c|c|}
\hline Sample & Day 1 & Day 30 \\
\hline Inoculum & 0.35 & 0.27 \\
\hline Hay 2.5\% & 0.74 & 0.36 \\
\hline Hay 5\% & 0.84 & 0.32 \\
\hline Hay 10\% & 0.85 & 0.39 \\
\hline
\end{tabular}

FOS/TAC data show that at the beginning of fermentation there is substrate overloading for all the samples and the inoculum itself is having a lot of degradable mates, but at the end of BMP, the test 
system is running at the maximum biogas production coefficient. This gives another evidence to tell that biogas formation is affected by the phenol concentration increase over the AF process.

\section{Surfactant usage in HHS digestion}

As indicated in Fig. 3, all types of surfactants leave a positive effect on the inoculum endogenous degradation process. The surfactants were added to the fresh inoculum sample taken from the last fermentation stage at the wastewater treatment sludge AF process. In this case, the BMP was not counted due to the small SAS input (only $350 \mathrm{mg} \cdot \mathrm{kg}^{-1}$ total mass for each). In this case, the total methane outcome was compared to understand the surfactant positive influence on inoculum AF. Non-ionic surfactants are enhancing the bio-methane production by $20 \%$, but anionic and cationic by $5 \%$ and $14 \%$, respectively (Fig. 3).

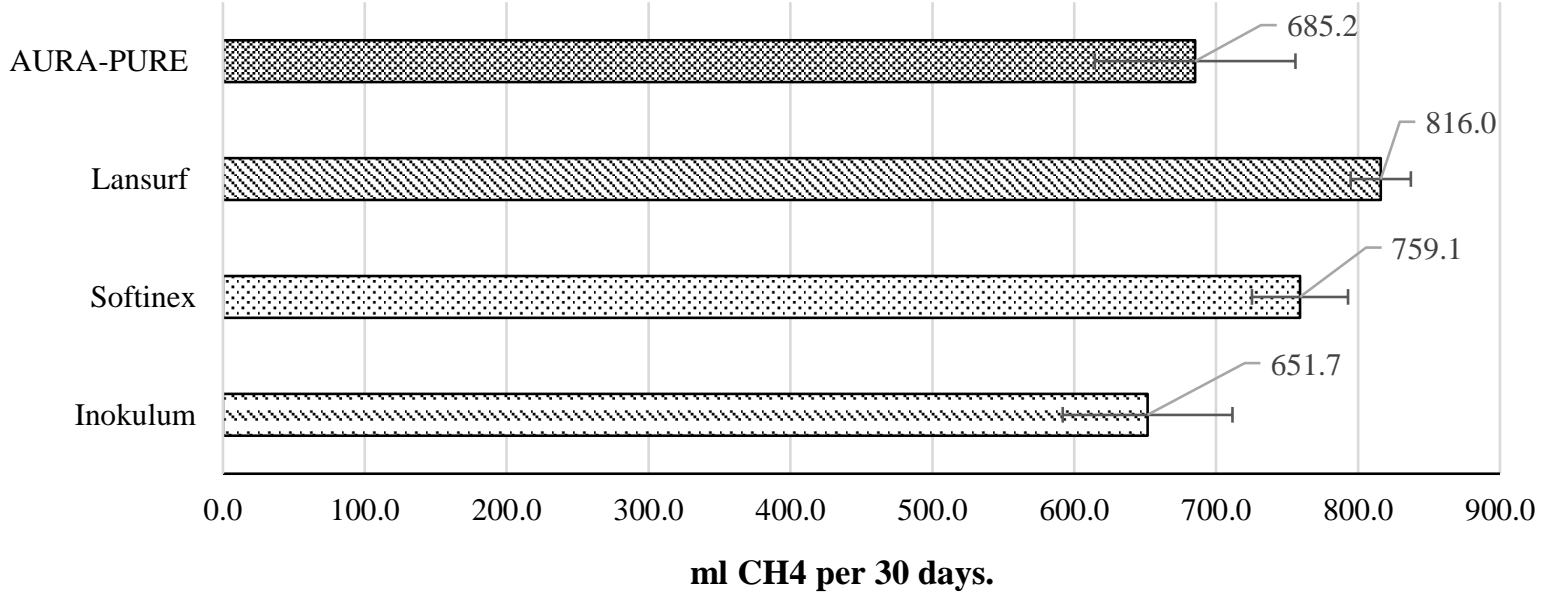

Fig. 3. Total $\mathrm{CH}_{4}$ outcome from inoculum in 30 days using different SAS

Surfactants have a great potential for wastewater treatment sludge AF enhancement. Generally, there are three influence mechanisms for the advancement of organic matter biodegradation by surfactant addition. Yu Z. et al. in their research about the SDS impact on AF mentions the first two mechanisms - micelle shapes made by surfactant and that surfactants are encasing the organic matter degradation. Therefore, microorganisms can adsorb the nutrients from the core of the micelles. In the second mechanism, surfactants enhance the mass transfer of contaminants and substrates to the aqueous phase to further degrade microorganisms, which are attributed to the reduced water surface tension by surfactant [28]. And the third mechanism is described by Aemig Q. in his research about polycyclic aromatic hydrocarbon biological degradation. He is reporting that cell hydrophobicity has been changed by the addition of surfactants, resulting in the direct contact between cells and contaminants, therefore faster mass transfer can take place [29].

After getting the evidence of the SAS positive influence on AF, it is useful to understand their interaction with HHS and how they can influence BMP potential changes. Fig. 4 shows the surfactant influence on BMP potential changes both with $2.5 \%$ and $5 \%$ HHS from total VS loaded.

Comparing to the previous fermentation using older substrate, the inoculum endogenous digestion shows $27 \%$ higher BMP than the previous fermentation, but HHS methane potential has decreased by 42 and $21 \%$ for hay loading of 2.5 and 5\%, respectively (Fig. 4). The main target for the experiments is to understand the relative impact on substrate loading and surfactant influence on AF, so in this case the differences in inoculum BMP are not so relevant. At the same time, the BMP decrease between 2.5 and $5 \%$ HHS loading remains similar $24 \%-285.1$ and $216.7 \mathrm{mlCH} 4 \cdot \mathrm{gVS}^{-1}$, respectively. SAS leaves a positive impact on both fermentation setups and statistically (double t-test for mean with $\alpha \leq 0.05$ ) it is equal to around $50 \%$ of BMP increase. The type of SAS is not playing a crucial role in the AF enhancement and all results are close to each other. In the case of anionic surfactant effect, when at $2.5 \%$ hay sample it gives the best BMP enhancement and at the same time at 5\% hay sample it gives the smallest enhancement of 55\% and 47\% respectively, giving the total BMP value of $629 \mathrm{mlCH} 4 \cdot \mathrm{gVS}^{-1}$ for sample hay $2.5 \%+\mathrm{AP}$ and $406.8 \mathrm{mlCH} 4 \cdot \mathrm{gVS}^{-1}$ for sample $5 \%$ hay $+\mathrm{AP}$. 


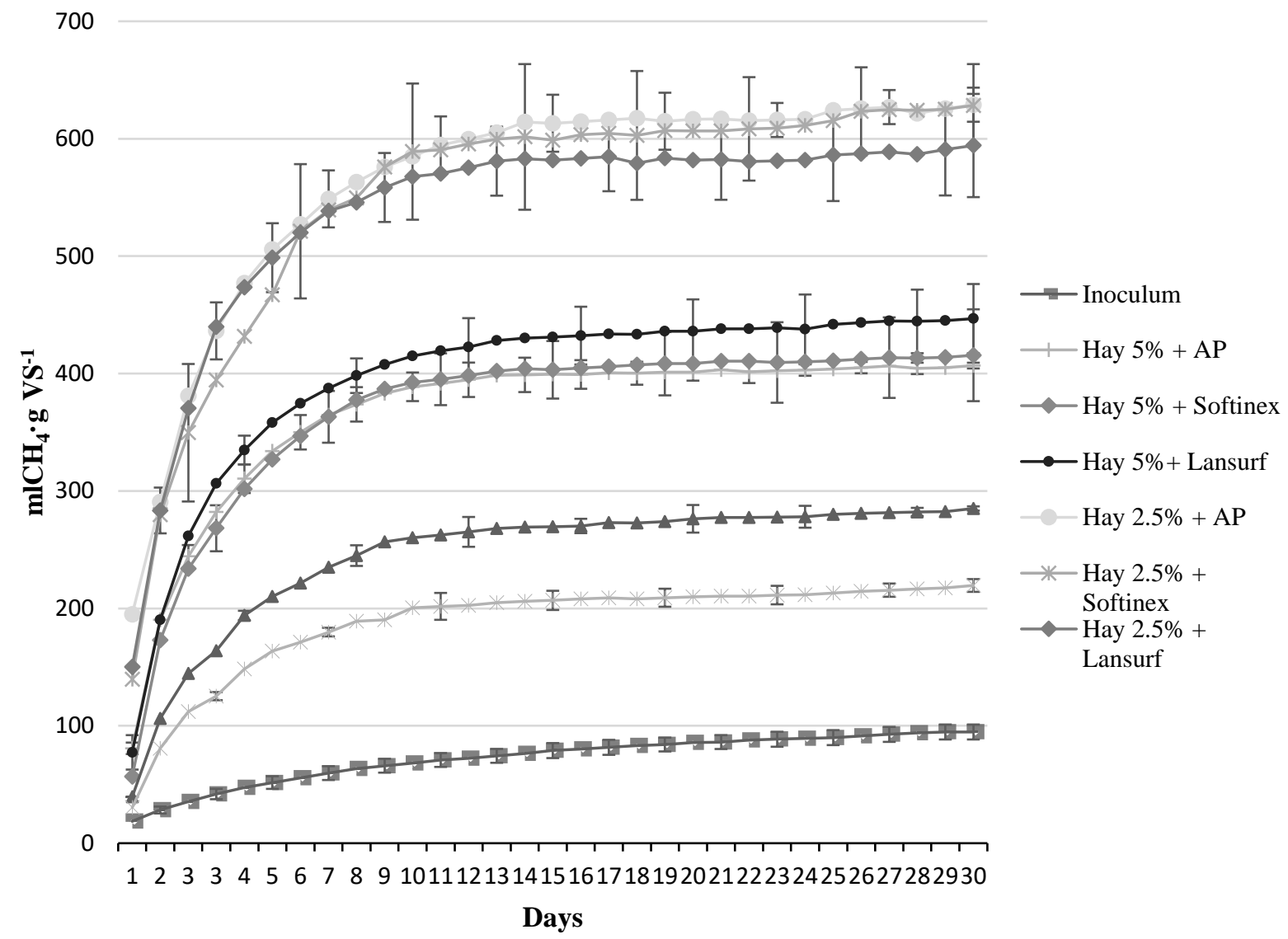

Fig.4. Hydrolysed hay substrate BMP changes under SAS influence

\section{Conclusions}

This research shows that biomass left after lignocellulose enzymatic hydrolysis for further renewable fuel production is a suitable co-digestion substrate for anaerobic fermentation. Therefore, anaerobic fermentation can be a powerful component in zero-to-low waste technology development for renewable fuel production from grassland biomass. Overleft hydrolyses substrate cannot be used as a primary substrate due to the substrate toxic effect starting at concentration higher than $2.5 \%$ from total VS loaded, but it still has the necessary abilities to be used as co-digestion feed stock. Biodegradable surfactants can act as fermentation enhancers and leave a positive influence on HHS biomethane potential increasing the BMP value from $47 \%$ to $55 \%$, depending on the HHS biomass loaded. At the moment, there is a lack of research about lignin degradation in the anaerobic fermentation process and this research opens a new discussion in lignin usage as the main feedstock for biogas production.

\section{Acknowledgment}

Research was supported by ERDF project No. 1.1.1.1./18/A/075 "Zero-to-low-waste technology for simultaneous production of liquid biofuel and biogas from biomass".

\section{References}

[1] International Energy Agency. Tracking Clean Energy Progress, IEA Publications: Paris, France, 2017; pp. 1-116.

[2] Sanchez O.J., Montoya S. Production of bioethanol from biomass: An overview. In Biofuel Technologies; Gupta, V.K., Tuohy, M.G., Eds. Springer: Berlin/Heidelberg, Germany, 2013, pp. 397-441.

[3] Mezule L., Berzina I., Strods M. The Impact of Substrate-Enzyme Proportion for Efficient Hydrolysis of Hay. Energies, vol.12 (18), 2019, 3526, pp.1-8. 
[4] Zervas G., Hadjigeorgiou I., Zabeli G., Koutsotolis K., Tziala C. Comparison of a grazing- with an indoor-system of lamb fattening in Greece. Livestock Production Science, vol.61 (2-3), 1999, pp. 245-251.

[5] Lynd L. R., Weimer P. J., Van Zyl W. H., Pretorius I. S. Microbial cellulose utilization: fundamentals and biotechnology. Microbiol. Mol. Biol. Rev., vol.66, 2002, pp. 506-577.

[6] Kumar D. Biochemical Conversion of Lignocellulosic Biomass to Ethanol: Experimental, Enzymatic Hydrolysis Modeling, Techno-Economic and Life Cycle Assessment Studies (Ph.D. thesis). Oregon State University, 2014.

[7] Arachchige A.R.P.P.W., Mezule L., Juhna T., Separation of reducing sugars from lignocellulosic hydrolysate: Membrane experiments \& system dynamic modelling, Agronomy Research, vol. 18(S1), 2020, pp. 1099-1106.

[8] Eriksson K. - E. L., Bermek H. Lignin, Lignocellulose, Ligninase. Encyclopedia of Microbiology, 2009, pp. 373-384.

[9] Mechichi T., Patel B.K., Sayadi S. Anaerobic degradation of methoxylated aromatic compounds by Clostridium methoxybenzovorans and a nitrate-reducing bacterium Thauera sp. strain Cin3, 4, Int. Biodeterior. Biodegrad., vol. 56, 2005, pp. 224-230.

[10] Wu Y.R., He J., Characterization of anaerobic consortia coupled lignin depolymerization with biomethane generation. Bioresour. Technol., vol. 139, 2013, pp. 5-12.

[11] Duan J., Huo X., Du W. J., Liang J. D., Wang D. Q., Yang S. C. Biodegradation of kraft lignin by a newly isolated anaerobic bacterial strain, Acetoanaerobium sp. WJDL-Y2. Lett. Appl. Microbiol., vol. 62, 2016, pp. 55-62.

[12] Ahmad M., Roberts J.N., Hardiman E.M., Singh R., Eltis L.D., Bugg T.D. Identification of DypB from Rhodococcus jostii RHA1 as a lignin peroxidase. Biochemistry, vol. 50, 2011, pp. 5096-5107.

[13] Wo, H. L., Ballor N. R., Hazen T. C., Fortney J. L., Simmons B., Davenport K., et al. Complete genome sequence of the lignin-degrading bacterium Klebsiella sp. strain BRL6-2. Standards in Genomic Sciences, vol. 9(1):19, 2014, pp. 1-9.

[14] Khan M. U., Ahring B. K. Lignin degradation under anaerobic digestion: Influence of lignin modifications - A review. Biomass and Bioenergy, vol. 128, 2019, 105325, pp.1-10.

[15] Mulat D. G., Dibdiakova J., Horn S. J. Microbial biogas production from hydrolysis lignin: insight into lignin structural changes. Biotechnology for Biofuels, vol.11(1):61, 2018, pp.1-16.

[16] Chapleur O., Madigou C., Civade R., Rodolphe Y., Mazéas L., Bouchez T. Increasing concentrations of phenol progressively affect anaerobic digestion of cellulose and associated microbial communities. Biodegradation, vol. 27(1), 2015, pp.15-27.

[17] Wang Y. T., Suidan M. T., Pfeffer T. J., Najam I. The effect of concentration of phenols on their batch methanogenesis. Biotechnol Bioeng, vol. 33, 1989, pp. 1353-1357.

[18] Rosenkranz F., Cabrol L., Carballa M., Donoso-Bravo A., Cruz L., Ruiz-Filippi G., Chamy R., Lema J. M. Relationship between phenol degradation efficiency and microbial community structure in an anaerobic SBR. Water Research, vol.47(17), 2013, pp. 6739-6749.

[19] Chapleur O., Madigou C., Civade R., Rodolphe Y., Mazéas L., Bouchez T. Increasing concentrations of phenol progressively affect anaerobic digestion of cellulose and associated microbial communities. Biodegradation, vol. 27(1), 2015, pp. 15-27.

[20] Yuan Q., Sparling R., Oleszkiewicz J.A. VFA generation from waste activated sludge: effect of temperature and mixing. Chemosphere, vol. 82, 2011, pp. 603-607.

[21] Xu L., Chen C., Li N., et al. Role of surfactants on the hydrolysis and acidogenesis of wasteactivated sludge. Desalinat Water Treatment, vol. 57, 2016, pp.16336-16345.

[22] He Q., Xu P., Zhang C. et al. Influence of surfactants on anaerobic digestion of waste activated sludge: acid and methane production and pollution removal. Critical Reviews in Biotechnology, 2019, vol. 39(5) pp. 746-757 (1-12).

[23] Jingura R. M., Kamusoko R., Methods for determination of biomethane potential of feedstocks: a review. Biofuel Research Journal, vol. 14, 2017, pp. 573-586.

[24] Hülsemann B., Zhou L., Merkle W., Hassa J., Müller J., Oechsner H. Biomethane Potential Test: Influence of Inoculum and the Digestion System. Applied Sciences, vol.10(7), 2020, 2589, pp.118.

[25]Lili M., Biró G., Sulyok E., Petis M., Borbély J., Tamás J. Novel approach on the bassis of FOS/TAC method. Conference: International Symposium "Risk Factors for Environment and Food 
Safety" \& "Natural Resources and Sustainable Development" \& "50 Years of Agriculture Research in Oradea", 2011, pp. 802-807.

[26] Golkowska K., Greger M. Anaerobic digestion of maize and cellulose under thermophilic and mesophilic conditions - A, comparative study. Biomass and Bioenergy, vol. 56, 2013, pp. 545 554.

[27] Wang Y. T., Suidan M. T., Pfeffer T. J., Najam I. The effect of concentration of phenols on their batch methanogenesis. Biotechnol Bioeng, vol. 33, 1989, pp. 1353-1357.

[28] Yu Z., Zhang C., Zheng Z., et al. Enhancing phosphate adsorption capacity of SDS-based magnetite by surface modification of citric acid. Appl Surf Sci., vol. 403, 2017, pp. 413-425.

[29] Aemig Q., Cheron C., Delgenes N., et al. Distribution of polycyclic aromatic hydrocarbons (PAHs) in sludge organic matter pools as a driving force of their fate during anaerobic digestion. Waste Manage., vol. 48, 2016, pp. 389-396. 